\title{
Development the Graphical Method of Calculating Structural Elements for Fixing a Gear in a Self-Centering Chuck through the Involute
}

\author{
Alexander S. Serkov \\ Omsk State Technical University, Mira 11, Omsk, 644050, Russia \\ Sanya_93@bk.ru
}

Keywords: Gear Manufacturing, Planetary Gears, Gearwheel Fixing, Grinding, Boring

Abstract. The article discusses the developed graphical method of calculating the size rolls diameter and the radius of their contact with the jaws.

\section{Introduction}

In the manufacture of gears (planetary gears, gearwheels), in the process of their production, there are difficulties related to ensuring the shape and size accuracy of the gearwheel hole involute profile, as well as their relative position relation to each other [1]. During chemical-thermal and heat treatments (cementation, hardening, etc.) of the gear, warping of its surfaces appears, an error of eccentricity arises. Therefore, finishing operations (grinding of working and base surfaces) are introduced into the technological process. The influence of the gear hole shape is described in [25].

In the gears manufacturing the final processing of its central hole, two fixing charts (locating, clamping) are mainly used:

1) along an involute profile through size rolls in a self-centering chuck [6-15];

2) along the outer contour of the gearwheel (without size rolls) in a self-centering chuck;

Initial data: $\alpha=20^{\circ}$ - profile angle of the initial contour; $r=22.5 \mathrm{~mm}$-the radius of the gearwheel pitch circle; $\mathrm{Re}=25 \mathrm{~mm}$ - outer radius of the gearwheel; $\mathrm{m}=2.5 \mathrm{~mm}$ - gearing module; $\mathrm{z}=18$ number of teeth. The analytical calculation of the device structural elements can be performed according to the method described in [16, p. 183].

The fixing chart calculation by the graphical method is carried out using a simplified way of drawing the tooth profile with the subsequent selection of the size rolls diameter, so that the contact points of the teeth profile with the rolls lie as close as possible to the radius of the gearwheel pitch circle. Let's consider this tracing with an example.

All tracings are performed on a computer in the modern computer-aided design system Compass V19.1 (Any other CAD system can be used for tracing).

\section{Main body}

From point $\mathrm{O}$ the radiuses of the circles $\mathrm{r}_{\mathrm{VP}}, \mathrm{r}_{\mathrm{O}}, \mathrm{r}, \mathrm{R}_{\mathrm{e}}$ (Fig. 1) are drawn. From point $\mathrm{O}$ at the gear vertical axis, angle $\varphi$ is postponed. From the point of intersection of the right angle $\varphi$ with the radius of the pitch circle, are being drawn a chord in both directions equal to $\mathrm{S}_{\mathrm{H}} / 2$ (the tooth thickness along the chord of the pitch circle). At both ends of the chord, points A and B are being mark. Point $\mathrm{A}$ is being connected with center $\mathrm{O}$ by a straight line. The center $\mathrm{O}_{1}$ are being found by dividing the line $\mathrm{OA}$ by 2 . From the center $\mathrm{O}_{1}$ the radius of the circle $\mathrm{R}_{1}=\mathrm{OA} / 2=\mathrm{r} / 2$ is being drawn crossing point $\mathrm{A}$, draw it to the intersection with the main circle radius $\mathrm{r}_{\mathrm{O}}$, find the point $\mathrm{O}_{2}$. Draw an arc $\mathrm{CAE}$ from point $\mathrm{O} 2$ with radius $\mathrm{R} 2$. The resulting curve is a tooth involute. Point $\mathrm{B}$ is being connected with center $\mathrm{O}$ with a straight line. Dividing line $\mathrm{OB}$ by two, we find the center 
$\mathrm{O}_{1}$ '. From the center $\mathrm{O}_{1}$ 'draw the radius of the circle $\mathrm{R}_{1}{ }^{\prime}=\mathrm{OB} / 2=\mathrm{r} / 2$, crossing point $\mathrm{B}$, draw to the intersection with the radius of the main circle $\mathrm{r}_{\mathrm{O}}$, find the point $\mathrm{O}_{2}{ }^{\prime}$. Draw an arc KBF from point $\mathrm{O}_{2}$ 'with radius $\mathrm{R}_{2}$ '. The resulting arch is a tooth involute. The CAEFBK points are the tooth profile outline. Using the function (mirror image relative to the gear vertical axis), is being obtained the profile of the second tooth. The teeth root is being constructed using a circle (a circle tangent to three curves - two involutes and the radius of the circle of the root $\mathrm{r}_{\mathrm{VP}}$ ). Circle is being entered $\mathrm{d}^{\prime}=5 \mathrm{~mm}$ between two teeth (diameter of the size rolls).

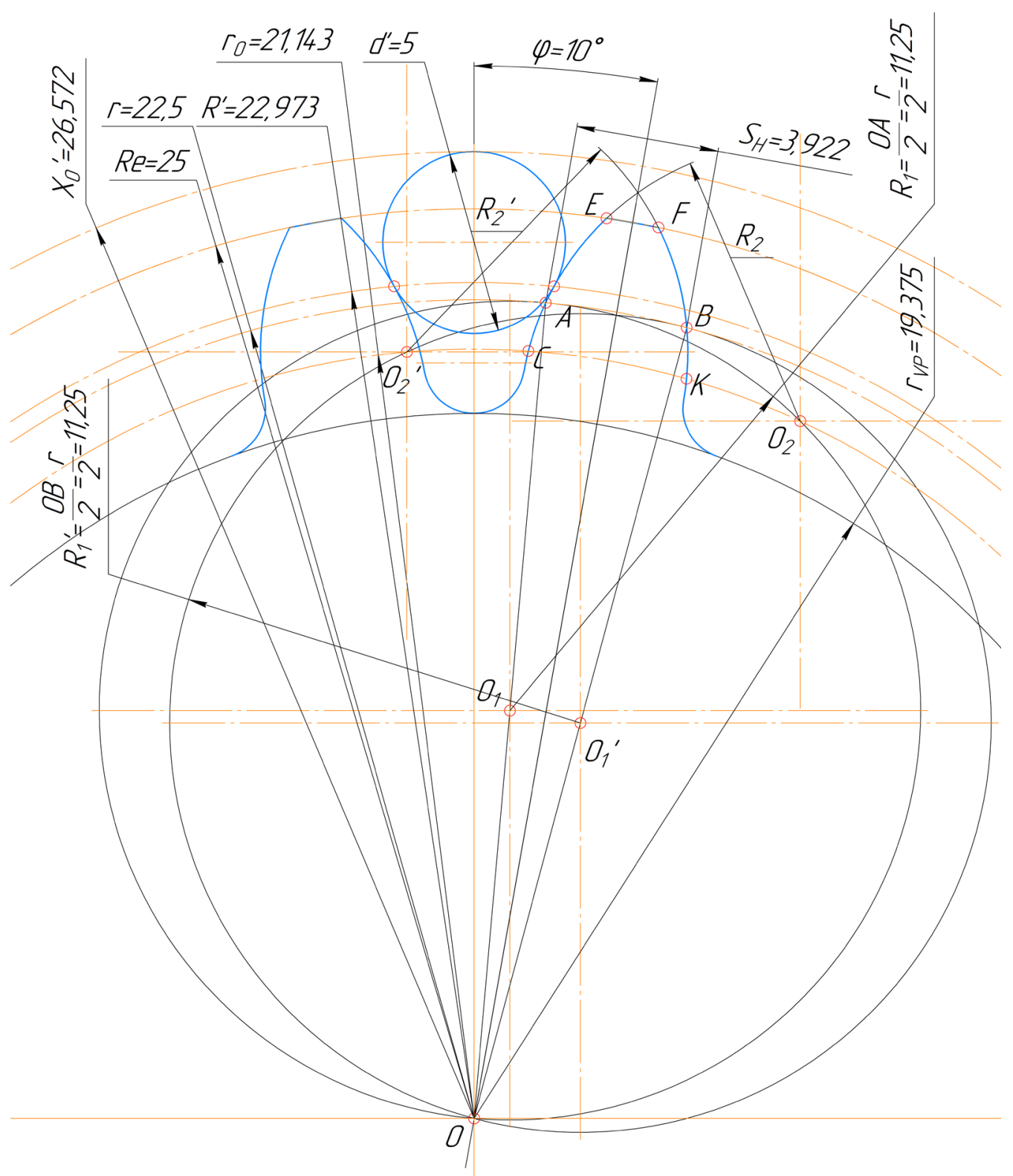

Fig. 1. Calculating chart for the roll diameter and the contact radius with the jaws by the graphical method. 
To determine the radius value of the circle on which the contact points of the roll with the teeth are located, using the snapping from the center $\mathrm{O}$, a circle draw through the contact points of the circle d 'with the teeth, graphically defining that $\mathrm{R}$ ' $=22.973 \mathrm{~mm}$.

To determine the value of the chuck jaws contact radius with the rolls at the moment of fixing when the gearwheels are being machined, from the center $\mathrm{O}$ a circumscribed circle is being drawn around the size rolls. Graphically are being determined that $\mathrm{X}_{\mathrm{O}}{ }^{\prime}=26.572 \mathrm{~mm}$.

\section{Conclusion}

The developed graphical calculation method is convenient for use in production, easy to understand, does not require calculating the engagement angle involute or finding its value in tables. It is possible to fully automate the construction of a tooth profile in CAD - Compass V19.1.

\section{Acknowledgments}

The reported study was funded by RFBR, project number 20-38-90226.

\section{References}

[1] A. S. Serkov, V. B. Masyagin, L. B. Serkova, Optimizatsiya tekhnologii proizvodstva shesterney, zubchatykh kolos, satellitov, Izvestiya Tul'skogo Gosudarstvennogo Universiteta. Tekhnicheskiye Nauki. 14 (2021) 134-139.

[2] O.V. Zhed', V.V. Kopylov, Vliyaniye formy otverstiya zubchatogo ventsa na yego predvaritel'noye napryazhonnoye sostoyaniye pri sborke s bazovoy detal'yu Chast' 1, Gruzovik. 12 (2017) $14-15$.

[3] O.V. Zhed', V.V. Kopylov, Vliyaniye formy otverstiya zubchatogo ventsa na yego predvaritel'noye napryazhonnoye sostoyaniye pri sborke s bazovoy detal'yu Chast' 2, Gruzovik.1 (2018) 18-22.

[4] V.A. Rogov, O.V. Zhed', Vliyaniye predvaritel'nogo napryazhonnogo sostoyaniya zubchatogo ventsa vsledstviye natyaga s bazovoy detal'yu v raschotakh na izgibnuyu prochnost' zuba, Tekhnologiya mashinostroyeniya.8 (2018) 31-39.

[5] O. Zhed, A.Koshelenko, K. Khishova, The effect of the stressed state of the ring gear due to interference with the base part in calculating the flexural strength of the tooth, IOP Conference Series: Materials Science and Engineering, 709 (2020) 022035-1-022035-8. https://doi.org/10.1088/1757-899X/709/2/022035

[6] A. S. Serkov, I. I. Sayfulin, O.V. Palina, Snizheniye sebestoimosti shlifovaniya posadochnykh otverstiy i tortsov tsilindricheskikh pryamozubykh zubchatykh koles za schot vnedreniya universal'noy osnastki, Innovatsii, kachestvo i servis v tekhnike i tekhnologiyakh, Kursk, (2017) 323-328.

[7] A.S. Serkov, L.B. Antropova, Vnedreniya universal'noy osnastki v operatsiyu shlifovaniya tsentral'nykh otverstiy tsilindricheskikh pryamozubykh zubchatykh kolos, Metrologiya, standartizatsiya i upravleniye kachestvom, Omsk (2018) 105-108.

[8] A.S. Serkov, L.B. Antropova, Shlifovaniye tsentral'nogo otverstiya tsilindricheskogo pryamozubogo zubchatogo kolesa s pomoshch'yu universal'noy osnastki, Problemy effektivnogo ispol'zovaniya nauchnogo potentsiala obshchestva, Sterlitamak, 3 (2019), 178-181. 
[9] A.S. Serkov, L.B. Antropova, Obrabotka otverstiya i tortsa tsilindricheskogo pryamozubogo zubchatogo kolesa s pomoshch'yu universal'noy osnastki metodom shlifova-niya, Nauchnyye revolyutsii: sushchnost' i rol' v razvitii nauki i tekhniki, Sterlitamak, 1 (2019) 33-36.

[10] A.S. Serkov, L.B. Antropova, S.F. Yeletskaya, Primeneniye universal'nykh trokhkulachkovykh patronov dlya shlifovaniya otverstiy v tsilindricheskikh pryamozubykh zubchatykh kolos, Metrologiya, standartizatsiya i upravleniye kachestvom, Omsk, (2019) 81-84.

[11] A.S. Serkov, Vnedreniye universal'noy osnastki v protsess shlifovaniya otverstiya i tortsa zagotovki satellita, Izvestiya Tul'skogo Gosudarstvennogo Universiteta, Tekhnicheskiye Nauki, 4 (2020) 316-320.

[12] A.S. Serkov, L.B. Serkova, YU.Ye. Zhdanova, V.B. Masyagin, Vnedreniye universal'noy osnastki v protsess shlifovaniye otverstiya i tortsa zagotovki satellita, Molodozh' i sistemnaya modernizatsiya strany: sbornik nauchnykh statey 5-y Mezhdunarod-noy nauchnoy konferentsii studentov i molodykh uchonykh, Kursk, (2020), 320-323.

[13] Information on http://www.avtomash.ru/gur/2005/20050244.htm

[14] Information on http://www.avtomash.ru/gur/2004/20041246.htm

[15] A.A. Malikov, G.V. Malakhov, A.V. Mikhaylov, Opredeleniye parametrov zubchatogo ventsa zagotovok s predvaritel'no oformlennymi zub'yami, Izvestiya Tul'skogo Gosudarstvennogo Universiteta, Tekhnicheskiye Nauki, 8 (2017) 344-353.

[16] KH. L. Bolotin, F.P. Kostromin, Stanochnyye prisposobleniya, M.: Mashinostroyeniye, (1973) 